NBER WORKING PAPER SERIES

\title{
UNION PARTICIPATION IN STRATEGIC DECISIONS OF CORPORATIONS
}

\author{
Eileen Appelbaum \\ Larry W. Hunter \\ Working Paper 9590 \\ http://www.nber.org/papers/w9590
}

\author{
NATIONAL BUREAU OF ECONOMIC RESEARCH \\ 1050 Massachusetts Avenue \\ Cambridge, MA 02138 \\ March 2003
}

We thank Reena Ganju for excellent assistance with the research on strategic labor-management partnerships. We benefited from hearing the views of Steve Early, Thomas Kochan, Larry Mishel, Richard Freeman, and other participants in the Conference on Emerging Labor Market Institutions. We also thank the labor representatives, managers, and researchers who shared their views on partnerships with us. The views expressed herein are those of the authors and not necessarily those of the National Bureau of Economic Research.

C2003 by Eileen Appelbaum and Larry W. Hunter. All rights reserved. Short sections of text not to exceed two paragraphs, may be quoted without explicit permission provided that full credit including Cnotice, is given to the source. 
Union Participation in Strategic Decisions of Corporations

Eileen Appelbaum and Larry W. Hunter

NBER Working Paper No. 9590

March 2003

JEL No. J53

\section{$\underline{\text { ABSTRACT }}$}

This paper reviews workforce participation in strategic decisions - those that affect the basic direction of the company - when workforce interests are represented collectively through unions. We consider the problem of corporate governance and review the rationale for what we term "strategic partnerships" between management and labor. The paper describes the prevalence of such partnerships in the U.S., focusing on two institutions through which unions have engaged in discussion of strategic issues: negotiated union-management partnership agreements, and union representation on corporate boards. We offer detailed accounts of specific strategic partnerships and of union involvement on corporate boards, showing that unions face a range of challenges in constructing partnerships that extend possibilities for effective representations of workers' interests.

Eileen Appelbaum

Professor and Director

Center for Women and Work

Rutgers, The State University of New Jersey

162 Ryders Lane

New Brunswick, NJ 08901

eappelba@rci.rutgers.edu
Larry W. Hunter

Assistant Professor of Management and Human Resources

School of Business

University of Wisconsin-Madison

4114 Grainger Hall

975 University Avenue

Madison, WI 53717

Lhunter@bus.wisc.edu 


\section{Introduction}

In the United States, the explicit representation of workforce interests in strategic decision-making processes of corporations is rare. Participation in strategic decisions those that affect the basic direction of the company - is unusual even when workforce interests are represented collectively through unions. In this chapter, we consider U.S. labor-management experiments with two institutions through which strategic participation for unions might be realized: negotiated union-management partnership agreements, and union representation on corporate boards.

These types of institutions for strategic participation have emerged from private sector initiatives, without the support of public policy. The ad hoc character of these U.S. initiatives stands in contrast to the legally mandated works councils, and provisions for workforce representation on corporate boards of directors (or "codetermination"), which are characteristic of many European countries. Europeans are in the process of constructing similar legally supported institutions for a united Europe. In the U.S., however, there are no legal structures that provide American workers with strategic participation at either the level of the establishment or the corporate board.

Understanding the development of these institutions in the U.S. requires consideration of the variety of attempts by unions and management to engage strategic decisions jointly.

This chapter examines union experiences with partnership agreements and with board representation. We begin by considering the problem of corporate governance and reviewing the rationale for strategic partnerships. The next section discusses the prevalence of such partnerships in the U.S. The following sections report on specific strategic partnerships and on union involvement in corporate boards of directors. The 
chapter concludes with discussions of the challenges and dilemmas facing unions should they seek partnerships at the strategic level.

\section{Corporate Governance in the U.S.}

Corporate governance is generally understood to refer to the legal and organizational structures that govern the relationship between corporate executives and the shareholders that are the ultimate owners of the physical capital of the company. Through corporate governance structures, firms make decisions about investments in plant and equipment, levels of staff and deployment of workers, location of operations, the allocation of resources, and the distribution of earnings. In theories of the firm that dominate U.S. legal and economic discourse, the purpose of corporate governance structures is to align the interests of corporate executives with those of the shareholders, and to assure that managers act in shareholders' best interests (Shleifer and Vishny 1997).

Shareholder-based theories reduce the relationship between owners and workers to an employment contract that specifies the wage - work effort bargain. In general, U.S. laws follow these theories: workers have no legally guaranteed rights to participation in corporate governance structures, or to have their interests taken into account when strategic decisions are made. While some states have allowed directors to consider other stakeholders (Orts 1992), most American corporate boards of directors have a primary fiduciary responsibility to the companies' shareholders. Shareholders in turn have legally recognized rights to be represented on corporate boards of directors, and to have the assets in which they have invested protected from misuse or misappropriation by the careless or opportunistic behavior of managers. 
Shareholder-focused conceptions of the firm, and their supporting legal structures, sharply differentiate decision-making managers from workers who do not make decisions. Such differentiation does not reflect contemporary practice, for effective management of modern enterprises requires more than the specification of a wage-effort bargain. Workers' engagement in decision-making began on a reasonably large scale in the U.S. with Quality of Work Life (QWL) programs in the 1970s (Appelbaum and Batt 1994; Heckscher 1997). Subsequent competitive pressures and technological developments led firms to adopt self-directed work teams and an array of high performance workplace practices that facilitated worker participation in operational decisions at the work site. These practices began slowly in the 1980s and became increasingly prevalent in the 1990s (Lawler, Ledford and Morhman 1989; Lawler, Mohrman and Ledford 1992; Osterman 1994; Freeman and Rogers 1995; Lawler, Mohrman and Ledford 1995; Gittleman, Horrigan and Joyce 1998; Osterman 2000) At the operational level, the benefits of involvement typically outweigh costs associated with joint decision-making. Empirical evidence demonstrates improvements in productivity, quality, delivery times, and even financial performance as a result of worker participation in operational decisions of the enterprise (Katz, Kochan and Weber 1985; MacDuffie 1995; Ichniowski, Shaw and Prennushi 1997; Appelbaum et al. 2000; Rubinstein 2000). (Becker and Gerhart (1996), Ichniowski et al. (1996), and Baker (1999) also review the evidence). These studies suggest that corporate management has an interest in implementing what have been termed "high performance work systems" Workers in high performance work systems also generally find that their jobs are more 
intrinsically satisfying and rewarding - more challenging and able to make better use of their skills (Appelbaum et al. 2000).

At decision-making levels above that of the day-to-day workplace, however, participation and partnership typically remain the prerogative of management. Managers have resisted calls for joint decision-making forums for decisions that might require downsizing, divesting of parts or whole divisions, or shifting operations to new locations or to other (often nonunion) subsidiaries, for example. Shareholders, similarly, may oppose decision-making processes that make it more difficult for owners to capture rents associated with innovations in technology, work systems, products or services. Managerial opposition to strategic participation by unions has often been strident (for an example, see Loughran (1985)).

Traditional collective bargaining by unions, within the existing framework of labor law, provides some constraints on managerial discretion. Unions have legally protected rights to negotiate over the effects of strategic decisions (though not the decisions themselves), and collective bargaining creates governance structures within firms that affect the distribution of resources, including the extent to which the firm's revenue is shared with the workforce, and the ways in which pay is allocated across workers. Unions may also negotiate to establish grievance procedures that provide a voice mechanism for workers who feel they have been treated unfairly by management, and for job rules and employment security arrangements that limit employers' ability to hire and fire at will.

Union leaders have been historically reluctant to involve themselves any more deeply in strategic decision-making than is called for under traditional collective 
bargaining. Such involvement might require them to assume responsibility for the performance of the company, or to participate in business decisions that may have disparate effects on different groups of union members, and labor leaders have not embraced such a role. Thomas Donahue, then AFL-CIO Secretary- Treasurer, summarized the traditional viewpoint in a 1976 speech:

Because American unions have won equality at the bargaining table, we have not sought it in corporate boardrooms. We do not seek to be a partner in management -- to be, most likely, the junior partner in success and the senior partner in failure. We do not want to blur in any way the distinctions between the respective roles of management and labor in the plant. We guard our independence fiercely -independent of government, independent of any political party, and independent of management.

\section{The rationale for strategic partnerships}

Collective bargaining has long been the primary vehicle through which unions have sought to protect the long-term interests of their members; high-performance work systems, coupled with union representation, may help workers and firms discover futher "mutual gains" in the workplace (Kochan and Osterman 1994). Even as new work practices diffused over the 1980s and 1990s, however, some union leaders came to believe that neither employee involvement nor collective bargaining provided unions with the means to deal with the turbulence associated with increasingly mobile capital, global competition, and corporate restructuring. For example, some evidence on the diffusion of new work practices suggests that such practices were not typically accompanied by provisions for employment security (Osterman 1994), and that firms that adopted them were in fact more likely than others to lay off workers in the 1990s (Osterman 2000). 
Workers tended to be favorably inclined toward new work systems, but their responses were less enthusiastic when reforms were coupled with corporate strategies that made jobs more precarious rather than more secure (Hunter, MacDuffie, and Doucet forthcoming). Union leaders began to observe that downsizing, outsourcing, and reengineering threatened their members even as the high performance work systems they had negotiated were delivering higher productivity and quality. These threats prompted more vigorous interest representation through collective bargaining, and more skeptical attitudes toward high-performance work systems.

Some unions also began to seek venues for engaging the strategic decisions themselves, looking for influence over the direction of the business, the allocation of resources, and the distribution of revenues, and for access to the financial information and business records upon which such decisions were based. While risky, these strategic partnerships may prove to be popular with union members: the Workplace Representation and Participation Survey (Freeman and Rogers 1999) provided some recent evidence that union members would support such institutions. Past opposition to such involvement may also have been overstated; an earlier survey by Fatehi-Sadeh and Safizadeh (1986), for example, showed that Illinois United Auto Workers (UAW) and AFL-CIO officials were favorably inclined toward strategic engagement.

Strategic partnership not only commands some support among workers, but also has an underlying economic rationale. This rationale is intensified in the current competitive environment, which features both continued downsizing and increasing use of high-performance work practices. Workers who invest in firm-specific skills - skills that do not transfer easily to other jobs - have a vested interest in the long-term 
performance of the firm that employs them. Further, high performance workplace practices require that workers, in order to participate effectively in operational decision making, make large investments in firm-specific skills (Appelbaum and Berg 2000). As with investments by shareholders in firm-specific physical capital, the returns to investments in these skills are earned over an extended time period as the company employs these skills to generate revenue. Should strategic considerations lead companies to lay off workers before they have the chance to recover the value of their investments in skills, U.S. workers, unlike their counterparts in many European countries, have no legally enforceable means to protect their investments. A role for unions in these decisions may therefore enhance the credibility of commitments made by managers, who themselves may be employed for relatively short periods and who may have incentives focused heavily on short-term performance.

U.S. firms also enjoy considerable freedom to oppose workers' right to organize, and to move work from union to non-union settings through outsourcing or investment strategies. These freedoms provide an important backdrop for the U.S. experiences with labor-management partnerships. On the one hand, because union leaders are centrally concerned with preserving union jobs, they have incentives to seek a variety of strategies, including partnerships, that might be effective in doing so. On the other hand, continued attention to institutional security on the part of the union leaders can distract from other issues that might be considered jointly. The ability of managers to walk away from labormanagement relationships, and, in some cases, their demonstrated willingness to do so, can erode the mutual trust necessary to make partnerships effective. 


\section{The prevalence of strategic labor-management partnerships}

Gray, Myers, and Myers's (1999) review of the Bureau of Labor Statistics file on contemporary collective bargaining agreements (those expiring between September 1, 1997 and September 30, 2007, and covering more than 1,000 employees) found that nearly $47 \%$ of U.S. collective bargaining agreements contained some form of "partnership." In this chapter, we focus on partnerships which include strategic engagement: negotiated agreements that provide the union with a voice in high-level decisions and with some influence over the governance of the company. Strategic partnerships enable unions to participate along with management in financial planning, in determining competitive strategy, and in decisions governing investments, technology, and production processes.

Gray et al. (1999) located the strategic partnerships that we discuss here at one end of a cooperation continuum, with modest arrangements (such as language indicating the intention of the parties to cooperate) at the other end, and provisions for employee involvement and information sharing somewhere between. A review of the collective bargaining agreements showed that strategic partnerships were extremely rare: only 27 of 1,041 contracts contained provisions for what Gray et al. termed "full partnership"; these contracts covered about 200,000 workers.

The history of some relatively high profile labor-management partnerships, such as the one that developed between Xerox and ACTWU (now UNITE) implies that strategic partnerships might evolve from shop-floor cooperation as a result of a sort of natural progression (see Appelbaum and Batt (1994) for an overview of this case). Gray et al. (1999), similarly suggest that partnerships may progress from low levels of 
cooperation, through more elaborate channels for employee involvement, to full strategic partnership.

We used this premise as a starting point for a small-sample inquiry. In the summer of 1999, we surveyed 25 researchers in management, human resource administration, industrial relations, and labor studies. Each had published studies examining negotiated labor-management cooperation; the studies covered 24 different companies. ${ }^{1}$ Many of these studies were assessments, negative as well as positive, of "high performance workplace" practices implemented through negotiated agreements.

Our survey focused on the extent to which negotiated cooperation, or lower-level partnerships, served as a precursor to subsequent involvement of the union in strategic decisions. Because the researchers were well positioned to provide a perspective with a longitudinal element, we asked them to describe the evolution of cooperation in the union-management relationship, and the extent to which strategic partnership had developed, emerged, or been negotiated.

We received usable responses from 12 researchers. Of these, five researchers reported that the union-management partnerships they studied led to no strategic participation for the union. At an information technology manufacturing company, for example, a partnership formed between corporate executives at company headquarters and the top levels of the union resulted in no high-level joint decision-making at the plant being studied. Similarly, a telephone company that had negotiated more cooperative

\footnotetext{
${ }^{1}$ The companies include GTE, NYNEX, NUMMI, AT\&T, Lucent, NCR, Saturn, Chrysler, US West, Pac Bell, GM Linden, ALCOA, Levi Strauss, Xerox, Harrison Radiator, Ford-Wayne ISA, Chrysler Canada, US Steel, Bethlehem Steel, Inland Steel, and companies in semiconductors, trucking, airlines, and steel that wished to remain unidentified.
} 
work practices with its union "never approached [strategic involvement]," according to the researcher who studied it.

Three researchers reported on companies and unions that negotiated cooperative relations, but not strategic partnerships, with the relationship blurring into discussions and consultation on strategic issues. The cooperative relation between the local union and management at one auto plant, for example, was described by a researcher as based on information sharing on business and operational matters. However, the relationship was never meant to be a strategic partnership. On the contrary, the researcher reported that "both parties jealously guard their rights and their obligations to their respective constituencies." This sort of partnership included communication, trust, consultation, and advance notice of changes; there was, however, no shared decision-making or union involvement in decisions relating to financial planning, investments, pricing, competitive strategies, or production processes.

Another researcher characterized an auto agreement similarly: "Dialogue is not the same as negotiation. Above all, it doesn't authorize any claim by the union to a legitimate place at the table.... In my opinion, management has been savvy and consistent in its efforts to promote worker participation (and not merely symbolic participation) while at the same time limiting the union to a fairly traditional role." Here, the union was informed and consulted prior to implementation of management decisions, but rarely involved in joint decision-making. For example, the company had already decided to adopt participatory workplace practices before it began any discussion with the union. It then involved the workforce extensively in the implementation of these practices. 
The remaining four researchers reported on full strategic labor-management agreements that accompanied other kinds of cooperation at five companies. Differences in the origins and evolution of these agreements are instructive. In the steel industry, strategic participation was driven by the United Steelworkers of America (USWA) national bargaining agenda (discussed in more detail below). The agenda includes a commitment to build strategic labor-management partnerships wherever possible in order to gain increased control over company decision-making. Researchers reported that companies in the steel and aluminum industries entered into strategic partnership agreements with the USWA because they needed to introduce new workplace practices in order to meet heightened global competition. The companies sought to redesign work processes, to increase discretionary effort, and by doing so to improve operational performance at the plant level; this required union participation. In practice, these partnerships have been implemented differently across companies and even across plants in the same company.

Telecommunications researchers described a contrasting case. Competition from non-union companies led one large company to enter into strategic partnership with the Communication Workers of America (CWA). The company wanted union support for favorable legislation and administrative rulings domestically as well as union help when it sought approval to participate in a foreign telephone company. This, it believed, would help the company compete and grow; the union supported these efforts because they were likely to result in more union jobs. The union made company neutrality in union organizing drives and card check recognition for the union key requirements for its participation in a strategic alliance at this and other telecom companies. According to the 
researchers, "The striking aspect of the union security clauses is that while the union began to demand [them] soon after divestiture, it met with limited success until the companies began needing union support in the regulatory arena. ... The union supported their efforts in return for some guarantees for union and job security.... The union won the union security clauses by linking regulatory and collective bargaining activities." Researchers suggested, however, that while CWA is involved in an alliance with the company about strategic issues, unlike the steelworkers, the union does not necessarily see shared decision-making authority as a key piece of its bargaining agenda.

Our survey of researchers is consistent with the data that show that strategic labor-management partnerships are rare. Even in cases where labor and management made commitments to cooperation at other levels, strategic involvement was unusual and did not typically follow other kinds of cooperation as part of an unfolding process. The survey suggested further that where such partnerships exist, they need not necessarily have evolved out of earlier experiences with negotiated cooperative relationships. Rather, there are a variety of paths to strategic partnership. We turn our attention to these paths next.

\section{The shape of strategic engagement: negotiated partnerships}

Some union leaders and companies have established strategic partnerships through negotiation. Below we consider in more detail the content of these partnerships, as well as the reasons that different unions and firms agreed to construct them. We do so with reference to four different partnerships, negotiated by unions in electrical contracting, telecommunications, steel, and manufacturing. 
Two primary kinds of interests - company growth (or stability), and new work practices -- have brought companies and their workers' unions together in strategic partnerships, Below we consider examples of each. First, as competitive pressures continue to intensify, companies and unions may find that they have a common interest in seeing the company grow. Growth of the company and expansion of union jobs, when these are mutually agreed upon goals, can be advanced by a partnership relationship. The cooperation of the union can help management preserve or increase market share, while the union sees involvement in defense or expansion of market share as an opportunity to protect and promote union jobs.

Second, at many companies increased competition also leads managers to introduce participatory management and high performance workplace practices. Strategic involvement can complement these practices. An active union role in decisions about workplace practices provides workers with a further voice and a forum for addressing the context in which the organization introduces new practices. Unions, like companies, have an interest in the adoption of practices that contribute to organizational viability and success. Mutual respect for both company and union goals can also be advanced by partnership relationships.

\section{Cooperative Efforts in the Electrical Construction Industry}

Perhaps the longest standing labor-management joint relationship in the U.S. is in the electrical contracting industry, between the International Brotherhood of Electrical Workers (IBEW) and the National Electrical Contractors Association (NECA). Composed of an equal number of representatives from the IBEW and NECA, the Council 
on Industrial Relations was established in 1920 as a judicial body to handle labormanagement disputes in the electrical construction industry. Disputes are submitted voluntarily, and all decisions are unanimous. The Council on Industrial Relations attempts to keep the industry free of strikes, serves as binding arbitrator for the industry, and meets to discuss safety and training matters. NECA and the IBEW also jointly operate the National Joint Apprenticeship and Training Committee for the electrical industry. This program was established in 1947 as the national coordinating arm for apprenticeship training. With a budget of approximately $\$ 80$ million a year, it operates more than 300 local apprenticeship training programs as well as in-service skill improvement training for electricians.

Building on these experiences with joint programs, NECA and the IBEW responded to competition from nonunion electrical contractors by establishing the National Labor Management Cooperation Committee (NLMCC) in 1995. In addition to more traditional functions, such as promoting mutual gains bargaining, the NLMCC functions as a strategic partnership between the thousands of union electrical contractors associated with NECA and the IBEW, which represents more than 300,000 electrical construction workers. About 4,200 electrical contractors are members of NECA and nearly 12,000 other union electrical contractors are "signatory" contractors who have indicated that they would like to be covered by the NECA contract. The NLMCC is funded at one cent per person-hour worked, or at about $\$ 3.5$ million per year.

Five years ago, in the context of its "Blueprint for the 90s," the NLMCC developed a "market recovery program" to take back market share from the vast number of small, nonunion contractors in the construction industry. Local NECA and IBEW 
groups work together to administer surveys to determine how much construction work is carried out by union contractors and union workers, and to develop programs for increasing the share of union work; the NLMCC helps to finance and conduct the surveys.

The program also includes joint campaigns to increase the number of apprentices, to create pride in the industry and union, and, especially, to promote the advantages of using union contractors. NECA and the IBEW jointly advertise union contractors and jointly hire sales people to market union contractors to builders and architects. Advertising emphasizes the skills and versatility of union electricians and the pride they take in doing their jobs well. "Quality Connection," an industry magazine published by the NLMCC, also supports this effort.

The IBEW described the market recovery program and the NLMCC as successful partnerships, noting that the number of union apprentices in the industry rose from 25,000 to 40,000 in the last half of the 1990 s. Further, in 1987 only about 28 percent of the electrical construction market was unionized. By 1999, according to IBEW, the market share of union contractors had risen to 37 percent of workers in the electrical construction industry.

\section{The Workplace of the Future in Telecommunications}

Concerns over market share and jobs also drove unions to seek strategic engagement in the telecommunications industry. One example comes from AT\&T, where the loss of monopoly protection in 1984 and the break-up of the Bell System led to a dramatic decline in union jobs. AT\&T eliminated over 60 percent of its unionized 
workforce between 1984 and 1992, while the regional Bell companies reduced the number of employees by about 30 percent through attrition (Batt, Katz, and Keefe 1999).

More than 100,000 CWA jobs were lost, and union leadership came to believe that traditional collective bargaining was limited in its ability to prevent further job losses. The smaller IBEW presence was also weakened: all IBEW jobs in some units, such as sales, were lost. The unions were concerned not only about the effects of restructuring on their membership, but about their own institutional security. In 1991, after acquiring NCR, a company that had aggressively used plant closures and other policies to avoid unionization, AT\&T allowed NCR to go forward with a full range of anti-union tactics. This occurred simultaneously with discussions AT\&T had begun with CWA about a code of conduct that would commit both the company and union to nonhostile behaviors during union organizing drives (Nissen 1998).

On the management side, AT\&T came to believe it would be able to compete more successfully if its union relationships were cooperative rather than adversarial. The company hoped that more cooperative relations with its unions would help it to expand its market share: unionized workers were heavily involved in customer service, and the company found it difficult, in a competitive environment, to gain new business and to retain customers while engaging in adversarial relationships with these workers and their representatives.

The partnership model negotiated between AT\&T and its unions, CWA and the IBEW, known as the Workplace of the Future, was intended to help all parties move from an adversarial to a more cooperative relationship. The partnership was kicked off in March 1993. The agreement states that "[t]he parties share the goals of establishing a 
world class, high performance organization and protecting employment security through market success," and recognizes that market success will require the company to target customer satisfaction and market flexibility (CWA 1993). Further, the agreement recognized that "[j]oint training, jointly designed, will be essential to develop common understandings, describe business strategies, and develop union expertise in new technology" (CWA 1993).

The partnership structure of the Workplace of the Future had four components. Workplace models, to be jointly defined by the company and its unions, were charged with identifying and managing the implementation of workplace practices that enhance quality, customer satisfaction, quality of work life, and competitiveness. Business Unit/Division planning councils were intended to facilitate participation by the unions in business decisions regarding technology, work organization, job content, training, and employment and in the development of cooperative work and leadership styles. The Constructive Relationship Council, established through bargaining in 1989, would continue to function and would facilitate the work of the Workplace Models and Business Unit/Division Planning Councils. Finally, a Human Resources Board, consisting of three AT\&T executives, one union leader each from the CWA and IBEW, and two distinguished leaders in the field of human resources, was established. The Human Resource Board was to address "broad, strategic, global human resources and business issues within the context of the external environment over long range time frames" (CWA 1993).

The various partnership structures called for in the Workplace of the Future agreement have provided the unions and workers with increased opportunities for 
participation, but the record has been uneven. The joint committees have not met the unions' expectations. The top level Human Resources Board has provided only limited opportunities for union participation in strategic decisions. It functions mainly as a means for the unions to obtain information from AT\&T.

The record of the partnership in promoting greater security for the workforce and for the union has also been mixed. Employment security language remains weak, and restructuring continues to cause great insecurity for workers. This problem has been especially acute for IBEW; CWA has had more opportunities to try to save jobs by suggesting alternatives to the company, or to mitigate the effects of downsizing on workers. The company, however, has not always accepted the unions' job-saving recommendations.

The partnership has been further strained by the unions' perception that AT\&T is hostile to the unions' institutional interests. For example, when CWA successfully organized a majority of the potential members at AT\&T's American Transtech to sign union cards, the company backed down on its neutrality pledge, embarking on an antiunion campaign. The union lost the 1995 representation election. More recently, the company has been buying into parts of the telecommunications industry that are nonunion, and resisting the unions' attempts to organize these workers. For example, AT\&T acquired TCI and Media One in order to get into the cable business, but these acquisitions were not discussed in the partnership. The long-term prospects of the partnership, in CWA's view, depend largely on whether AT\&T agrees to neutrality when the unions undertake organizing drives to represent workers in its cable operations. 


\section{$\underline{\text { New Directions Bargaining in Steel }}$}

In the decade following the 1982 collapse of steel production in the U.S.,

integrated steel mills were idled, employment fell, and wage and benefit concessions led to sharp declines in real compensation for steelworkers. In 1992, the USWA adopted its New Directions bargaining program, seeking “an ongoing voice for itself and its members in managerial decisions affecting shop-floor, plant, and corporate performance, all with an eye toward producing business success sufficiently sustained and shared as to serve both company and worker interests on a continuing basis." (Frankel 1997:3). The program, according to USWA President George Becker, calls for "employment security guarantees and partnership agreements providing for union and worker involvement at every level from a seat on the Board of Directors to problem-solving on the shop floor." (Becker 1998: 120).

Building on its 1986 partnership agreement with National Steel, the USWA introduced New Directions bargaining in the 1993-94 round of contract negotiations. The main provisions of the New Directions program include a no layoff guarantee; union involvement in workplace and corporate decision making; restructuring the work place to increase flexibility, improve productivity, and reduce costs; and neutrality and card check recognition when the union seeks to organize nonrepresented employees (Frankel 1997). The program also included a strategic alliance between the company and the union with respect to public policy and joint company and union responses to industry trends. The union successfully negotiated contracts that included these partnership provisions with the major integrated steel companies - Inland, National, Bethlehem, USX, and LTV. Contracts with other companies, including Wheeling-Pittsburgh, Republic Engineered 
Steels, USS/Kobe, Acme, J\&L Specialty, Lukens Steel, Gulf States, and Northwestern Steel and Wire, contained many of the substantive features of the New Directions program. The agreements were for 6 years, and have been renegotiated since August 1, 1999. Partnership agreements remain an important part of the unions' bargaining agenda, and have been renegotiated with the major integrated steel companies.

The partnership agreement provides the union with the right to participate, along with company managers, in decisions at levels of the company. At the corporate level, joint strategic partnership committees bring union leaders and company executives together to consider strategic plans, technological change, staffing levels, customer evaluations, major organizational issues, and facilities utilization. The agreements also include mechanisms by which union and plant officials can negotiate over instituting modern work practices, plant steering committees investigate alternative approaches to safety, work redesign, work assignments and scheduling, planning for technological change, training, and process improvement.

The New Directions Bargaining Pattern contains provisions that require the steel companies to remain neutral when the USWA seeks to organize their nonrepresented employees and, in most cases, to recognize the union once a majority of workers has signed union cards. The strength of these provisions was tested quickly after their adoption: in the 1993-94 contracts, such provisions covered only those affiliates in which the steel company directly or indirectly owned more than 50 percent of the voting power. LTV subsequently took exactly a 50 percent stake in a mini-mill in Gadsden, Alabama in the union's view, to evade the neutrality provisions - and the USWA put the partnership it had negotiated with the company in 1993 on hold. Both workers and the 
union refused to participate in problem solving and decision making activities. In the 1999 bargaining round, the neutrality provisions were extended to cover any entity in which the steel company owns a material interest and whose business involves steel raw materials or steel production and distribution. LTV agreed to accept these provisions and to withdraw from its joint venture in the Alabama steel mill if its partners refused to remain neutral during a USWA organizing drive.

The acquiescence of LTV to the neutrality provisions suggests that the withdrawal of the workers and union from involvement in decision making and from cooperation in plant committees had consequences for performance at LTV's integrated mills. More generally, Appelbaum and Berg (2000) report that the partnership program of the USWA played an important role in increasing the legitimacy of worker involvement on the shop floor from the perspectives of both workers and managers, observing that employment security provisions assure individual workers that they will not work themselves out of a job if they use their capacities to innovate to contribute to increased productivity. The new workplace practices, these authors show, were associated with significantly higher productivity, and contributed heavily to the return to profitability of the integrated mills and to the turnaround in the steel industry.

The extent to which these partnership agreements have been implemented by union and management officials varies widely, as does the extent to which union officials participate in strategic decisions at the corporate level. Some local unions and managers have been able to use the partnership agreement to engage in mutual gains bargaining, but other facilities have experienced resistance from union officials or local managers to the basic elements of cooperation and partnership. Both union officials and managers 
express skepticism about whether the New Directions partnerships in steel live up to expectations about union participation in top-level strategic decisions. But the partnerships have proven valuable to both steel companies and the USWA as a means to modernize workplace practices, improve the economic viability of the integrated steel mills and the strength of the union as an institution, and preserve or expand union jobs in the industry.

\section{High Performance Work Organization Partnerships}

The International Association of Machinists and Aerospace Workers (IAMAW) has successfully launched HPWO Partnerships or is far along in the process at approximately 50 (out of several thousand) of the facilities at which it represents workers. Union locals and managers at a far larger number of work sites have taken some early steps toward developing a partnership. Some of the best known partnerships are being developed at leading companies such as Harley Davidson or Weyerhauser, but partnerships have also been established at small or medium-sized companies, often family-owned. The union intends the HPWO Partnerships to enhance employers' competitive position and thus its members' job security and welfare. Partnerships have been developed with companies that wanted to increase market share in the face of intense competition, as well as with those facing severe financial or competitive problems that pose a threat to their survival.

IAMAW observes that partnerships must begin with the commitment of management to growth; this commitment enables the union's joint participation in developing and implementing a strategy and business plan to achieve that growth. In the 
view of the union, if all management and the union do "is increase productivity and efficiency and do not develop strategies to stabilize and grow the business and get control of costs, employees may improve their way out of employment" (International Association of Machinists and Aerospace Workers 1999: 8-1). IAMAW identifies three components of a successful partnership: a business plan that incorporates long-term returns, market expansion, and growth of the workforce; accurate costing out of all the activities that support production of the products and services the firm offers in the market place; and changes in the work process that improve quality and productivity.

Partnership agreements establish a governance structure at the corporate or establishment level to provide leadership and guide the development of a growth strategy. The corporate partnership committee at Harley Davidson, for example, comprises four union and two company representatives. In an ideal partnership, a jointly developed strategic plan charts the future of the business. Only after the union and management have agreed on a growth strategy and an appropriate system for costing activities will the union agree to assess work processes jointly and to propose improvements. The introduction of high performance workplace practices follows, rather than precedes, the development of the partnership. Extensive education, training and planning go into developing HPWO Partnerships. Several years may elapse between the time the union and company agree to explore a partnership relationship and the time an agreement is implemented.

Partnership structures also include decision making bodies at the workplace, such as business unit or plant-level teams, that determine appropriate measures to track performance and make decisions about work processes and implements changes, 
including the adoption of just-in-time inventory, self-directed work groups, cellular manufacturing, and so on. Shop stewards meet on a daily basis with their salaried counterparts, and natural work groups gather and share information, analyze problems and engage in problem solving activities, and make daily operational decisions. (International Association of Machinists and Aerospace Workers 1999). To assist its local unions in this process, the IAMAW also has a five-person department that provides consulting and training and seven field staff that provide support services; particularly in smaller companies, top managers have welcomed advice on business process improvement and the development of alternative products and workplace practices.

In addition to the commitment to growth and the establishment of joint decisionmaking structures, the IAMAW has several other aims for its high performance work organizations. These include agreement on employment security, development of an education and communication plan for all employees, and an implementation plan for replacing traditional top down decision making by managers with joint decision making by labor and management at the appropriate levels of the organization. The union expects to be "recognized as a valued and trusted partner by management." At the same time, "the institutional support and protection provided by the union for the Partnership helps employees accept new roles and explore new work methods" (IAMAW 1999: 6-5).

Many of the HPWOs have been established under difficult competitive circumstances, in firms and plants that have the inefficiencies typical of older manufacturing systems. The trying circumstances have provided a motivation for cooperation, but have also made it difficult to establish trust, develop joint governance and decision-making structures, or to make fundamental changes in work processes. 
Obstacles to successful partnerships include the difficulty of taking on new roles for managers, professionals, other salaried employees, union leaders, and workers. For example, engineers and supervisors may fear that they have much to lose from the Partnerships, and may be reluctant to participate in the process. Further, under competitive duress, managers experience more pressure to turn to layoffs, and the union may interpret consideration of such options as less than trustworthy. Shop floor frustration with the pace of change or skepticism about management's motives can lead to rejection of union leaders, or of contracts that include partnership agreements.

Yet a partnership that provides a commitment by management and the union to jointly developing a proactive approach to addressing competitive pressures may be the key both to survival for the company and to employment security for workers. The partnership may also increase the union's strength as it comes to be seen by its members as providing real leadership to ensure the employer's long-term survival and growth, thereby preserving jobs.

\section{Union Representatives on Corporate Boards of Directors}

Our reviews and descriptions of partnerships are consistent with the finding that fewer than $3 \%$ of major collective bargaining agreements feature these arrangements: full partnerships appear to be extremely difficult for unions to establish and maintain. American unions have no statutory support for strategic involvement, and few firms have actively sought the involvement of union leaders at this level. The construction of these forums has required unusual circumstances, strong common interests in surviving in difficult competitive environments, and determined union leadership. 
Negotiated strategic partnerships occupy precarious ground. They are vulnerable to collapse where union members are skeptical of the value of such involvement. Their survival and effectiveness also depend heavily on management commitment to the partnership, since information sharing and joint decision-making are integral parts of strategic involvement. What is less clear is whether unions can force such commitment upon management given sufficient bargaining power, or whether commitment depends in part on the good faith of management.

Several American unions, aware of the tenuous nature of negotiated partnerships, have sought to bolster their strategic influence further by seeking seats on the boards of directors of companies where they represent members. Board seats could be particularly valuable in strategic partnerships because directorships come with statutory rights to information and involvement in decisions. Such seats have emerged as a target of collective bargaining in programs such as the USWA's New Directions and the IAMAW's HPWO.

Board seats for unions are not always coupled with other joint approaches or a commitment to partnership in decision-making. Throughout the 1970s and 1980s, unionnominated directors resulted chiefly from negotiations over ownership for workers through the institution of Employee Stock Ownership Plans (ESOPs) (Hunter 1998). Protection of the workers' ownership interests, rather than an increased commitment to shared strategic decision-making, motivated union leaders to seek board representation in many of these cases.

At least three factors constrain union-nominated directors' abilities to use the board as a forum for discussions of management and union interests in strategic 
decisions. First, union nominees, like all directors on American corporate boards, are required to represent the interests of shareholders (for a more complete description of this responsibility, see Johnson, Daily, and Ellsrand 1996), and are legally liable should they fail to do so effectively. Their fiduciary duties typically proscribe directors from explicit representation of union interests on boards, except where they can argue that meeting union interests is consistent with protecting shareholders' investments in the firm.

A second constraint on interest representation in the boardroom is normative: the view of the proper role of corporate boards that pervades American managerial and directors' communities. On typical boards, outside directors -- those not part of the executive team -- rarely involve themselves with issues of day-to-day governance. Only major events such as takeovers or changes in top executives bring forth outside director activism (Useem 1993). Board functioning in less dramatic circumstances relies on consensus rather than constituency representation or explicit negotiation among competing interests.

Third, managers' interests are not always aligned with those of the firms' shareholders, and managerial opposition to shared control can derail strategic engagement even in when it is to the benefit of shareholders. Here the experiences of the International Brotherhood of Teamsters (IBT) with board nominees are especially instructive. Following deregulation and the weakening of pattern bargaining in the 1980s. trucking companies sought wage concessions. In several firms, workers accepted stock in return for wage concessions; the IBT insisted on board seats to accompany the stock plans. Several of the Teamster-nominated directors envisioned these seats as vehicles to foster joint discussion of the strategic issues facing the firm and union, but this never 
developed. Instead, the boards became the venues through which the IBT attempted to protect its members' financial investments as the firms struggled. The managers guarded information closely and made as many decisions as possible outside the boardroom. Most of the IBT boards were characterized by considerable mistrust between outside directors and inside managers: one Teamster-nominated director actually sued the managers of his firm. All of the Teamster board schemes eventually disappeared as the firms were acquired or went bankrupt in the fierce competition that followed deregulation.

Awareness of the legal, normative, and practical constraints has dimmed union enthusiasm in board representation as a forum for strategic engagement. Chrysler, for example, was the first large American company to have a union representative on its board, with UAW President Douglas Fraser obtaining a seat following the concessions associated with Chrysler's near bankruptcy in 1980. In 1984, after some wrangling, Fraser's successor as President, Owen Bieber, assumed the seat. The Chrysler-UAW seat illustrated the limits of board representation: both Fraser and Bieber found it difficult to influence management policy in this venue. After several years, the UAW did not emphasize preservation of the board seat as a bargaining objective. The corporation restructured its board, dropping Bieber, in 1991.

Nevertheless, experiments with board representation continue. Table 1 lists American firms in which union representatives have recently served on corporate boards of directors. Typically, these boards have one or more directors, but fewer than a majority, nominated by a union; the board seats are written into either the collective bargaining contract or, where backed by share ownership, the ESOP agreement. With 
the exception of the airlines, the firms have directors representing members of only one union; airline boards comprise members of both the Airline Pilots' Association (ALPA) and the IAMAW. In addition to the American firms listed in Table 1, the United Auto Workers are represented on the 20-person supervisory board of directors of at the German company Daimler-Chrysler. Under German law, the unions that represent Daimler-Chrysler workers in Germany are entitled to three seats; the German union IG Metall has allowed the current UAW President to assume one of these three seats.

Though union officials (including presidents of international unions such as Bieber and Fraser) have held directorships, union board representation does not require the directors to be active unionists or workers. The IAMAW, for example, discourages active union leaders from serving on boards; among its representatives are a number of retired union officials. Another common approach is the nomination of friendly "neutrals" - consultants, lawyers, even college professors - to serve as directors. Some of these union-nominated directors have been effective in improving firm governance in the interests of shareholders (Hunter 1998). Many union-nominated directors have the characteristics that corporate governance theorists claim make directors effective: a strong interest in the well-being of the company; sources of information; independence from management; and ties to important stakeholders (Baker and Patton 1987). Union nominees with the right skills, commitment, and support can be as effective contributors to governance as any other outside director.

A few of the boards of companies in Table 1 have established themselves as forums that reinforce or enhance strategic partnerships between labor and management. Most typically, this occurs when both parties are committed to the success of the schemes 
in ways similar to those detailed in other kinds of strategic partnerships: the board seats are seen by the parties as part of a broader approach to labor-management cooperation, and the parties have strong reasons for cooperation rooted in the demands of the competitive market. Wever's (1989) case study of the Western Airlines board, for example, showed that board participation was stronger when accompanied by further forms of employee involvement, and that all these forms of involvement were stronger when unions were more powerful and secure. As with other partnerships, the institutional security of the union, and the perception of the union that management will not (or is not powerful enough to) undermine that security, are important prerequisites for success.

Despite the legal, normative, and practical constraints, union-nominated directors have had influence on strategic decision-making in a number of areas. Cagy or experienced directors can turn the consensus-seeking environment in their favor, stalling or delaying decisions by withholding approval, for example. Union-nominated directors may diminish the likelihood that managers will seek to implement plans that will be perceived by the unions as divisive or destructive. Typically, they can do so by using their board positions to raise issues for discussion, and by requiring managers to address the argument that plans that provoke union opposition may be bad for the company (and its shareholders) in the long term.

Directors also affect the selection and compensation of top executives. Union nominees can push to hire managers who are relatively more committed to partnership and to protecting the institutional interests of the union, for example, and may be able to stall or block the appointments of managers that they believe would be hostile. Directors can also ensure that executive pay packages are established (and explained to the 
workforce) in ways consistent with the preservation of partnership, rather than in ways that breed distrust or discontent.

Board members can also be helpful in preserving a role for collective bargaining while placing it in strategic context. While bargaining is required over the distribution of returns, the presence of union representatives on boards can help both sides to make their positions credible to the others: books are relatively more open, for example, and directors can establish additional channels for communication. More generally, the presence of union-nominated directors adds additional credibility to strategic planning, while providing another route through which workforce and union concerns can be incorporated into decisions that affect the future of the company.

While board representation can facilitate aspects of partnership, such as information sharing, it is clear that such representation provides no guarantees that the parties will work together to address joint concerns amicably. In addition to the difficulties at Chrysler and the problems the Teamsters had, other well-publicized fiascos with union board seats have included the Rath Packing Company (Hammer and Stern 1986), Hyatt-Clark (Labor Research Review 1985), and Eastern Airlines (Smaby 1988). United Airlines provides a recent example of the challenges that union-nominated directorships face. ALPA and the IAM obtained one seat each on the board of directors, along with share ownership, in 1994. (The flight attendants did not join in the plan, though non-union employees also took partial ownership and one board seat.) Directors have struggled since then to establish their roles. As do all directors, the union nominees owed fiduciary responsibilities to all shareholders. Yet they owed their seats, and their loyalties, to the unions that had nominated them. On the board, directors formally 
represented employees' ownership interests. In practice the distinction between these interests, the interests of employees in their jobs, wages, and working conditions, and the interests of the unions as institutions tended to get tangled up.

Following the employee buyout, board representation did not emerge as a catalyst for further cooperative approaches to labor-management relations. Over time, the likelihood that an effective partnership would be established diminished as trust between top managers and the union eroded. A difficult round of bargaining in 1997 was followed by a dispute over the IAM's organizing of passenger service agents. An on again-off again proposal for a merger with USAirways provided further controversy. Eventually, the difficulties in the relationship began to have detrimental effects on company performance. In summer 2000 pilots were accused of engaging in work slowdowns (pilots' spokesmen denied the accusations), and the bargaining between United and the IAM that continued through summer 2001 was bitter even by industry standards. The airline's performance did not improved relative to its competitors after the buyout (Gittell, von Nordenflycht, and Kochan 2001), and none of the parties saw the ESOP as a success story.

\section{Concluding remarks: dilemmas for unions}

Strategic partnerships in the U.S. seem unlikely to evolve naturally from other kinds of partnerships or employee involvement programs. Managers will continue to seek employee involvement in the workplace, should they believe it will enhance performance, but are less likely to bring unions into the executive suite. Public policy developments that would mandate, or even encourage, strategic partnerships between 
unions and management also seem exceedingly unlikely. We therefore conclude this chapter with remarks that focus on the dilemmas that strategic partnerships raise for unions and their leaders, for the development of this new institution depends primarily on union initiative, and the extent to which unions find ways to address these challenges.

There are at least three kinds of orientations that unions have brought to strategic partnerships. The first is limited: where workers have invested in the firm through stock purchases and ESOPs, unions can negotiate for ways to monitor managers more carefully from an investor's point of view. Second, partnerships can be primarily defensive, focused on company growth or stability and on the corresponding preservation of union jobs. Growth and security have provided premises underlying both successful and unsuccessful partnerships. Third, the partnership may be part of an overall attempt by the union to involve itself more deeply in the management of the firm, in which the union seeks venues through which its own expertise and that of its members can be deployed in ways that promote firm performance.

Participation presents a set of dilemmas to unions at the local level (Frost 2000), with the commitment of local workforce representatives to programs for labormanagement participation greatly enhancing the chances for success of such efforts. Such commitment, however, requires local unionists to reinterpret and redefine their roles, and to convince their members of the value associated with cooperation (Kochan 1985).

Strategic participation from any orientation, whether exercised through negotiated partnerships or through board seats, raises challenges that may be more difficult for unions to address. Problems with participation are intensified because the stakes are high. By definition, the issues taken up at the strategic level may profoundly affect job 
security, and the future survival of the firm and the union. Historically, union leaders have been averse to accepting even partial responsibility for managerial decisions without corresponding authority or influence, and they remain skeptical that partnerships will provide true influence. Successful strategic partnerships therefore require unions to assess accurately the extent to which management is willing to participate, or can be forced to do so.

The primary rationale for union-management strategic partnerships is to promote the long-term competitive position of the firm in directions consistent with protection of the workers' investments in the firm, whether in financial or in human capital. In some environments, the parties may not have enough common interests to make partnership viable. As Heckscher and Shurman (1997) note, a potentially "fatal problem" with partnerships is that they cannot address the turbulence outside the firm that seems to be endemic to the current economy.

To gain workers' support, strategic partnerships must protect not only workers' investments, but the institutional security of the union itself. Union leaders are likely to see any purported benefits of partnership as vacuous in the presence of threats to the continued vitality of labor representation for the firms' workers. One promising area for further investigation is the relationship between union organizing and strategic partnerships. Through strategic partnerships, unions have sought to establish conditions of neutrality toward further organizing and toward treatment of acquisitions. Where partnerships have floundered, on the other hand, it is often because the unions have been unable to forge this kind of arrangement. Keeping union jobs inside the firm rather than outsourcing the may be a similar precondition for success. 
Even where the parties have enough common interests to warrant cooperation, further factors also mitigate against the success of strategic partnerships. Among these factors are mismatches between union structure and the demands of partnerships, and the failure of partnerships to include all relevant parties (Hecksher and Shurman 1997). Strategic participation and partnerships raise dilemmas for the union as an institution, at levels above that of the local, the bargaining unit, or the company. Effectiveness of strategic partnerships, whether through negotiated agreements or in the boardroom, can be greatly enhanced by the support and involvement of the international union. The cooperation of the international can provide directors and local leaders in partnerships with access to information and expertise, and international unions have the resources to train and guide local leaders.

International unions, however, are also charged with setting industry frameworks for bargaining, and with establishment of common standards and principles. This creates problems for the international with respect to strategic participation. As one union leader remarked,

"When I talk about a conflict of interest I'm not really talking about the simple union-management problem. The issue is really single enterprise loyalty. I don't want me or the [international] union to be in a position of playing God, to be picking winners in the industry" (quoted in Hunter, 1998).

Strategic engagement and partnerships, however, may push international unions in the direction of favoring some members' interests over others, precisely because such institutions are intended to confront competitive issues. Strategic decisions that help one firm may harm another; a dilemma for international union leaders is to establish principles for support of partnerships that will enable them to avoid being caught up in 
such intra-industry competition. Internationals, and hence partnerships, are more likely to be effective where circumstances permit the partnership to focus on competitive challenges that do not raise such internal problems for the union (for example, attacking the non-union sector in electrical contracting).

Strategic partnerships may also require the commitment of substantial union resources, both to the achievement of the partnership (since management is often opposed), and to its support and maintenance. With the benefits of strategic engagement unclear, unions may be reluctant to provide the required levels of support; few unions besides the USWA and ALPA, for example, have identified strategic partnerships as an objective of collective bargaining, and the USWA is currently reassessing the prominence it has assigned to this goal. Within the CWA, similarly, the future of partnerships is being debated, with skeptics questioning the commitment of the union's time and resources to participation at the expense of activities such as organizing.

Union-management strategic partnerships also may exclude from the discussion parties that are necessary to the long-term success of the firm (Heckscher and Shurman 1997). For example, inside the firm, middle managers and supervisors may go unrepresented, yet their reactions may strongly affect the success of strategic initiatives or the introduction of new work systems. Further, partnerships must be matched to the appropriate level of organizational decision-making: corporate-level partnerships may be ineffectual in a highly decentralized management structure, for example, while effective division- or plant-level partnerships may be undone with a single decision made at corporate headquarters should the union find the decision objectionable. 
Table 2 brings together in summary form a range of choices available to unions in the design of these institutions. The choices union leaders make will depend on a number of factors: internal union politics and structure; the particular features of the competitive markets in which the firms seek to compete (the extent of unionization, global competition, or competition on the basis of price, for example); the bargaining power of the union at the local and international levels; and the relationship and history union leaders have with local and corporate-level management.

These choices, for now, will be made in a legal environment that is fits unionmanagement partnerships poorly. Generally, American labor laws provide relatively weak protections of workers' rights to organize. Even in unionized firms, managers typically oppose vigorously any attempts to extend union representation, and seek opportunities to move work from union to non-union environments. Union involvement in strategic decision-making tends, therefore, to be concentrated on preserving membership. In the absence of such security, union leaders find it difficult to engage in the kinds of cooperation that would permit the parties to confront the kinds of threats to employees' job security and earnings that could be addressed by joint efforts such as those directed toward training or the implementation of high-performance work practices.

Little legal guidance exists on how partnerships should be conducted even where the parties find ways to establish them: on the extent to which union leaders might compromise their duty of fair representation to their members in the exercise of their fiduciary duties as board directors, for example, or how they might reconcile duties of representation with decisions made in the process of strategic planning. Directors also enjoy little legal guidance on the extent to which they are allowed to share information 
with the unions that nominate them to boards. Management lawyers tend to advise union nominees to share nothing, which is hardly consistent with the spirit of the arrangements. Anti-trust law governing interlocking directorates is also vague in its application to these contexts, and with respect to whether international unions can send representatives to multiple firms. Further, the extent to which conflicts of interest requiring union nominated directors to remove themselves from discussions is debatable both in theory and practice. Several boards have considered, with different results, whether the presence of the union representatives in the boardroom is appropriate during discussions of collective bargaining strategy. Negotiated partnerships, while less burdened by legal requirements than are directorships, operate in a legal vacuum. The further emergence of both these forms of partnership should be considered in the surrounding legal context, and changes in that context merit close attention for those interested in strategic participation.

\section{References}

Appelbaum, E., T. Bailey, P. Berg, and A. Kalleberg (2000). Manufacturing Advantage: Why High Performance Work Systems Pay Off. Ithaca, NY, Cornell University Press.

Appelbaum, E. and R. Batt (1994). The New American Workplace: Transforming Work

Systems in the United States. Ithaca, NY, Cornell University/ILR Press. 
Appelbaum, E. and P. Berg (2000). "High-Performance Work Systems: Giving Workers a Stake." The New Relationship: Human Capital in the American Corporation. M. M. Blair and T. A. Kochan. Washington, DC, Brookings Institution: 102-144.

Baker, T. (1999). Doing Well by Doing Good: The Bottom Line on Workplace Practices. Washington, DC, Economic Policy Institute.

Batt, R., H. C. Katz and J. Keefe (1999). "The Strategic Initiatives of the CWA:

Organizing, Politics, and Collective Bargaining." Paper presented at the Symposium of Changing Employment Relations and New Institutions of Representation, Sloan School of Management, MIT, May 25-26. Ithaca, NY, Department of Human Resources, Cornell University.

Becker, B. and B. Gerhart (1996). "The Impact of Human Resource Management on Organizational Performance: Progress and Prospects.” The Academy of Management Journal 39(4): 779-801.

Becker, G. (1998). “A History of Advocating Labor/Management Cooperation.” New Steel 14(March): 120.

CWA (1993). Workplace of the Future. Washington, DC, Communications Workers of America. 
Donahue, Thomas (1976). Speech at the International Conference on Trends in Industrial and Labor Relations, Montreal, Quebec, Canada, May 26, 1976.

Fatehi-Sadeh, K., and Hossein Safizadeh (1986). "Labor Union Leaders and Codetermination: an Evaluation of Attitudes." Employee Relations Law Journal 12(2): $188-204$.

Frankel, C. B. (1997). New Directions Bargaining in the American Steel Industry. Pittsburgh, United Steelworkers of America.

Freeman, R. and J. Rogers (1999). "Worker Representation and Participation Survey: First Report of Findings." Proceedings of the Forty-Seventh Meeting of the IRRA.

Frost, Ann C. (2000). "Explaining Variation in Workplace Restructuring: The Role of Local Union Capabilities.” Industrial and Labor Relations Review, 53 (4), forthcoming.

Gittell, J. H., A. Von Nordenflycht, and T. Kochan (2001). "Mutual Gains or Zero Sum? Labor Relations and Stakeholder Outcomes in The Airline Industry." Manuscript.

Gittleman, M., M. Horrigan, and M. Joyce (1998). “'Flexible' Workplace Practices: Evidence from a Nationally Representative Survey.” Industrial and Labor Relations Review 52(1 (October)): 99-115. 
Gray, G., D. W. Myers, and P. S. Myers (1999). “Cooperative Provisions in labor agreements: a new paradigm.” Monthly Labor Review 122(1): 29.

Hammer, T.H. and R. N. Stern (1986). "A Yo-Yo Model of Cooperation: Union Participation in Management at the Rath Packing Company." Industrial and Labor Relations Review, Vol. 39, No. 3, pp. 337-49.

Heckscher, C. and S. Shurman (1997). "Can labour-management cooperation deliver jobs and justice." Industrial Relations Journal 28 (4): 323-330.

Hunter, L.W. (1998). "Can Strategic Participation be Institutionalized? Union Representation on American Corporate Boards," Industrial and Labor Relations Review $51(4): 557-578$.

Hunter, L.W., J.P. MacDuffie, and L. Doucet (forthcoming). What Makes Teams Take? Employee Reactions to Work Reforms," Industrial and Labor Relations Review.

Ichniowski, C., T. A. Kochan, D. Levine, C. Olson, and G. Strauss (1996). "What Works at Work: Overview and Assessment." Industrial Relations 35(3): 299-333.

Ichniowski, C., K. Shaw, and G. Prennushi (1997). “The Effects of Human Resource Management Practices on Productivity: A Study of Steel Finishing Lines.” The American Economic Review 87(3): 291-313. 
International Association of Machinists and Aerospace Workers (1999). High Performance Work Organization Partnerships: Field Manual. Upper Marlboro, MD, IAMAW.

Johnson, J. L., C. M. Daily, and A. E. Ellstrand (1996). "Boards of Directors: A Review and Research Agenda." Journal of Management 22 (3): 409-438.

Katz, H. C., T. A. Kochan, and M. R. Weber (1985). “Assessing the Effects of Industrial Relations Systems and Efforts to Improve the Quality of Working Life on Organizational Effectiveness." Academy of Management Journal 28(3): 509-526.

Kochan. T.A., ed. (1985). Challenges and Choices Facing American Labor. Cambridge, Mass.: MIT Press

Kochan, T. A. and P. Osterman (1994). The Mutual Gains Enterprise : Forging a Winning Partnership among Labor, Management, and Government. Boston : Harvard Business School Press.

Labor Research Review, 1(6) (1985). "The Hyatt-Clark ESOP: An Interview with Jim May," 25-33. 
Lawler III, E. E., G. E. Ledford Jr., and S. A. Mohrman (1989). Employee Involvement in America: A Study of Contemporary Practices. Houston, American Productivity and Quality Center.

Lawler III, E. E., S. A. Mohrman, and G. E. Ledford Jr (1992). Employee Involvement and Total Quality Management. San Francisco, Jossey-Bass.

Lawler III, E. E., S. A. Mohrman, and G. E. Ledford Jr (1995). Creating High

Performance Organizations. San Francisco, Jossey-Bass.

Loughran, C. S. (1985). "Union Officials as Corporate Directors: What Price Survival?" Directors and Boards, $\underline{10}$ (1).

MacDuffie, J. P. (1995). “Human Resource Bundles and Manufacturing Performance: Organizational Logic and Flexible Production Systems in the World Auto Industry." Industrial and Labor Relations Review 48(2): 197-221.

Nissen, B. (1998). "Fighting the union in a 'union friendly' company: the AT\&T/NCR case.” Labor Studies Journal 23(3): 3.

Orts, E. W. (1992). "Beyond Shareholders: Interpreting Corporate Constituency Statutes." George Washington Law Review 61 (1): 14-135. 
Osterman, P. (1994). "How Common is Workplace Transformation and Who Adopts It?" Industrial and Labor Relations Review 47(2): 173-188.

Osterman, P. (2000). "Work Reorganization in an Era of Restructuring: Trends in Diffusion and Effects on Employee Welfare." Industrial and Labor Relations Review 53(2): 179-196.

Patton, A. and J. C. Baker (1987). "Why won't directors rock the boat?" Harvard Business Review, $\underline{87}(6), 10-21$.

Rubinstein, S. (2000). "The Impact of Co-Management on Quality Performance: The Case of the Saturn Corporation.” Industrial and Labor Relations Review 53(2): 197-218.

Smaby, B. (1988). "Labor-Management Cooperation at Eastern Air Lines." Washington, D.C.: U.S. Bureau of Labor-Management Cooperation, U.S. GPO.

Shleifer A. and R. Vishny (1997). “A Survey of Corporate Governance,” Journal of Finance 52: 737-783.

Useem, M. (1993). Executive Defense: Shareholder Power and Corporate Reorganization. Cambridge, Mass.: Harvard University Press 
Wever, K. R. (1989). “Toward a Structural Account of Union Participation in Management: The Case of Western Airlines." Industrial and Labor Relations Review, 42(4): 600-609. 
TABLE 1

SOME U.S. COMPANIES WITH UNION-NOMINATED BOARD DIRECTORS (circa 2000)

\begin{tabular}{|c|}
\hline Algoma Steel \\
Allegheny Teledyne \\
Bethlehem Steel \\
Cable Systems International \\
Cleveland Cliffs \\
Hawaiian Airlines \\
J\&L Specialty \\
LTV \\
Maryland Brush Co. \\
National Steel \\
Northwest Airlines \\
TWA \\
United Airlines \\
Weirton Steel \\
Wheeling Pittsburgh \\
\hline
\end{tabular}


TABLE 2

CHOICES FACING UNION LEADERS IN THE DESIGN OF INSTITUTIONS FOR STRATEGIC PARTNERSHIP

\begin{tabular}{|c|c|c|c|}
\hline $\begin{array}{l}\text { TYPE OF } \\
\text { CHOICE }\end{array}$ & $\begin{array}{l}\text { INTERNATIONAL } \\
\text { UNION }\end{array}$ & $\begin{array}{l}\text { INTERNATIONAL } \\
\text { OR LOCAL } \\
\text { UNION }\end{array}$ & LOCAL UNION \\
\hline $\begin{array}{l}\text { Establishment } \\
\text { of partnership }\end{array}$ & $\begin{array}{l}\text { Does the international } \\
\text { union advocate } \\
\text { partnerships as a } \\
\text { matter of policy? } \\
\text { Does the union } \\
\text { support board seats? } \\
\text { Does the union } \\
\text { support negotiated } \\
\text { strategic } \\
\text { partnerships? } \\
\text { What policy should } \\
\text { the union demand of } \\
\text { the company with } \\
\text { respect to subsequent } \\
\text { organizing } \\
\text { campaigns? }\end{array}$ & $\begin{array}{l}\text { Does the union } \\
\text { bargain for } \\
\text { partnership } \\
\text { structures? } \\
\text { If management is } \\
\text { reluctant to agree, } \\
\text { how much is } \\
\text { partnership worth? } \\
\text { How should future } \\
\text { organizing } \\
\text { campaigns and } \\
\text { acquisition of non- } \\
\text { union operations be } \\
\text { handled? }\end{array}$ & $\begin{array}{l}\text { Should workers buy } \\
\text { stock in their own } \\
\text { company? } \\
\text { Should partnerships } \\
\text { accompany concession } \\
\text { bargaining? } \\
\text { What role should } \\
\text { employment security } \\
\text { guarantees play in the } \\
\text { partnership agreement? }\end{array}$ \\
\hline $\begin{array}{l}\text { Identity of } \\
\text { union } \\
\text { representatives } \\
\text { in strategic level } \\
\text { decisions }\end{array}$ & $\begin{array}{l}\text { Should active } \\
\text { international union } \\
\text { leaders be permitted } \\
\text { to involve themselves } \\
\text { in governance } \\
\text { decisions of } \\
\text { individual } \\
\text { companies? }\end{array}$ & $\begin{array}{l}\text { What criteria will } \\
\text { be used to select } \\
\text { representatives? }\end{array}$ & $\begin{array}{l}\text { Who will the } \\
\text { representatives be? }\end{array}$ \\
\hline $\begin{array}{l}\text { Continuing } \\
\text { support for } \\
\text { representatives }\end{array}$ & $\begin{array}{l}\text { Will the international } \\
\text { union provide } \\
\text { training and technical } \\
\text { support for the } \\
\text { representatives? }\end{array}$ & $\begin{array}{l}\text { Will the union } \\
\text { attempt to } \\
\text { coordinate with or } \\
\text { instruct the } \\
\text { representatives? }\end{array}$ & $\begin{array}{l}\text { Will structures be } \\
\text { established for } \\
\text { communication between } \\
\text { representatives, local } \\
\text { union leaders, and local } \\
\text { members? }\end{array}$ \\
\hline
\end{tabular}

